Nieswiadomy, M.L. \& Straazicich, M.C. (2004). Are Political Freedoms Converging?" Economic Inquiry, 42(2), 323340 (April 2004). Published by Wiley-Blackwell (ISSN: 0095-2583). [The definitive version is available at

www3.interscience.wiley.com]

\title{
Are political freedoms converging?
}

\author{
Michael L. Nieswiadomy and Mark C. Strazicich
}

\begin{abstract}
This article tests for convergence of freedom using Freedom House's (2002) indices of political rights and civil liberties in 136 countries from 1972 to 2001. Time-series tests, using structural breaks, are employed to test for stochastic and [beta]-convergence. Cross-section tests are performed to examine the impact of legal systems, education, natural resources, economic freedom, and other variables. We find that political freedoms are converging for one-half of the countries. Additionally, we find that the level of freedom is significantly related to the legal system, education, economic freedom, and natural resources.
\end{abstract}




\section{INTRODUCTION}

This article examines the Freedom House (2002) index of political rights and civil liberties in 136 countries to test if political freedoms are converging. Recently, Helliwell (1994), Barro (1996; 1999), and Minier (2001) find evidence that the level of income is a significant determinant of political freedom or democracy. In this article we pose a related question: will political freedoms converge? We address this question empirically by testing if political freedoms converge in the framework of the Solow (1956) growth model. An important implication of Solow's (1956) model is that per capita incomes converge in the long-run steady-state. Given heterogeneous savings rates, population growth rates, and technologies, the Solow (1956) model predicts that per capita incomes will converge "conditionally" to country-specific steady-states or "compensating differentials." Convergence implies that economies with relatively low initial incomes will grow faster compared with economies with relatively high initial incomes to catch up. Numerous empirical studies find evidence that national per capita incomes are conditionally converging (see, e.g., Baumol 1986; Barro 1991; Barro and Sala-i-Martin 1992; Mankiw et al. 1992; Evans 1996; Evans and Karras 1996; Scully and Bass 1998; Li and Papell 1999). Given evidence that political freedom is related to income and a preponderance of evidence that incomes are converging, an interesting question to posit is whether political freedoms are converging.

To perform our empirical tests for convergence, we employ three time-series methodologies. First, we use a simple analysis to determine if the coefficient of variation of political freedom is decreasing over time. Friedman (1992) notes that Hotelling (1933) referred to the coefficient of variation test as "the real test of a tendency of convergence." Next, we follow the approach of Carlino and Mills (1993) and test for stochastic convergence. Stochastic convergence implies that the log of political freedom in country i relative to the world average is a stationary (or trend stationary) process. Given convergence, shocks to freedom in country i relative to the world will be temporary. Structural breaks are allowed in our tests for stochastic convergence. Finally, we utilize a time-series test of [beta]-convergence to determine if estimates of intercepts and trends are consistent with convergence. Convergence implies that countries with freedom levels below the world average will have positive growth in freedom and vice versa.

In spite of some evidence of convergence, freedom levels are not equal for many countries. As a result, we want to analyze factors that might significantly impact the level of freedom. In particular, we examine the relationship between political freedom and the legal system, educational attainment, natural resource dependency, and economic freedom, among other variables, in a cross-sectional analysis. Overall, our findings suggest that political freedoms are converging for approximately half of the countries. Additionally, the legal system, education, economic freedom, and natural resources are significantly related to the level of freedom.

The article proceeds as follows. Section II provides a brief background discussion. Section III describes the data. Section IV discusses our testing methodologies. Section V examines our empirical findings. Section VI summarizes and concludes. 


\section{BACKGROUND}

Hayek (1960) defines freedom as the absence of coercion by government. Political freedom is generally measured in terms of security of political rights and civil liberties. One of the most widely cited indices of political freedom among nations is the annual index of political rights and civil liberties published by Freedom House (2002). These measures of political freedom have been receiving increasing attention in recent years (see, e.g., Barro 1999; La Porta et al. 2001; Banaian and Luksetich 2001). However, no previous study has tested if political freedoms are converging.

A growing literature has developed that examines the determinants of political freedom, or democracy, and effects on economic welfare. (1) Lipset (1959) and Huntington (1991) argue that economic development increases the demand for democracy. For example, as a country becomes more developed and integrated into the world economy, its denizens are exposed to democratic ideas espoused in other countries and demand more democracy. As such, given convergence of incomes, one can hypothesize that over time countries will converge to the same level of political freedom. Helliwell (1994) finds evidence that the level of democracy is positively related to per capita real gross domestic product (GDP) and secondary school enrollment. Barro (1996) argues that political freedom is a luxury good, that is, that improvements in the standard of living increase the probability that countries will become more democratic. In a related paper, Minier (200l) examines "democratic movements" in authoritarian nations and finds that the demand for democracy increases with per capita income up to approximately US $\$ 5,000$ (1985\$) but decreases thereafter.

Barro (1999) notes that theoretical models delineating effects of economic conditions on political freedom are not well developed. His analysis utilizes panel data using seemingly unrelated regressions with over 100 countries at approximately five-year intervals from 1960 to 1995 . He utilizes an array of variables that have been widely cited in political science literature and tests for significant factors affecting democracy. He finds that the propensity for democracy increases with per capita real GDP, primary schooling, and a smaller gap in male and female primary school attainment, but declines with a greater economic dependency on natural resources. He additionally finds that the effect of colonial heritage is minimal and the effect of religion is small, except for a significant negative effect of Muslim religions. Though Barro's (1999) work makes an important contribution to the literature by modeling the time path of political freedom within countries, the time path between countries is not examined.

\section{DATA}

\section{Dependent Variable}

Throughout our empirical tests, the level of political freedom is modeled as our dependent variable. Since 1972, Freedom House (2002) has evaluated and reported two measures of political freedom in their annual Freedom in the World survey. We use both measures of freedom: political rights and civil liberties. Political rights allow people to participate freely in the 
political process. In a free society all adults can vote and compete for public office, and elected representatives make decisive votes on public policies. Civil liberties include the freedom to develop views, institutions, and personal autonomy apart from the state. The Freedom House (2002) survey ranks political rights and civil liberties in each country on a scale of 1 to 7 , with 1 representing the most freedom and 7 the least. Initial ratings are assigned to countries (or territories) by awarding from zero to four raw points per checklist item, depending on the comparative rights or liberties present. The highest possible score for political rights is 32 points, based on four points for each of eight questions. The highest possible score for civil liberties is 56 points, based on 4 points for each of 14 questions. Freedom House (2002) only reports the index numbers on the 1-to-7 scale and not the raw scores. To perform our tests, we create a composite index of political freedom by summing the index of political rights and civil liberties. Then we invert the composite index so that a higher number indicates a higher level of freedom and a lower number a lower level of freedom; thus the highest (most free) score is 14, and the lowest is 2. (2)

\section{Cross-Section Explanatory Variables}

As previously noted, the level of political freedom in each country is influenced by several factors. Several variables hypothesized to affect long-run country-specific levels of political freedom are examined. In particular, we examine differences in legal systems, educational attainment, natural resource dependency, and economic freedom, among other variables. Because this model uses a cross-section of countries in 2001, no convergence tests are conducted per se. Rather our cross-section tests examine the association of several factors with a recent measure of political freedom.

Legal System. The legal system's impact on freedom is of paramount importance according to Hayek (1973), who stated, "The ideal of individual liberty seems to have flourished chiefly among people where, at least for long periods, judge-made law predominated." The effect of legal system has been studied in several different contexts. La Porta et al. (1998) show that countries having the English common law tradition provide greater protection for investment than those with a French civil law tradition. Mahoney (2001) shows that common law countries experienced faster economic growth than those with civil law from 1960-92, primarily through greater security of property and contract rights. Following the literature, we use Reynolds and Flores's (1989) definitions of the legal system. Countries are defined according to two broad traditions: English common law or Roman civil law (La Porta et al. 1998). The primary difference in these two legal structures is common law's emphasis on case law as opposed to civil law's reliance on written law. Common law countries generally grant more power to the judiciary as a check on executive and legislative actions than in civil law countries. An interesting aspect of these differing legal structures is that they are largely exogenous because most countries obtained their legal system through colonization or conquest (Mahoney 2001). We include an additional category of Muslim law. Because the extent of Muslim law varies, we use two measures for common law and Muslim law. (3) In our first set of models, a dummy variable (Common) equals one if the country is primarily described as having common law (and no 
Muslim law) and zero otherwise. The corresponding Muslim law dummy (Muslim Any) equals one if the country has any Muslim law present. For the second set of dummies, Common Strict equals one if the country has primarily common law and Muslim Strict equals one if the country has predominately Muslim law. Civil law is the base case in all of the models. Classifications of legal structures are shown in Appendix Table A1. We do not include any communistic (past or present) countries in the appendix. Following Hayek (1973), we hypothesize that countries with predominately common law will have higher levels of political freedom than those with predominately civil law. We expect Muslim law countries to have low levels of freedom. The lack of freedom in Arab countries is increasingly noted as a significant impediment to human development (United Nations Development Programme 2002).

Educational Attainment. The educational attainment of a country may also affect the ability of political freedoms to converge. For example, a more educated citizenry may be more cognizant of the benefits of freedom and demand more. Following Barro (1999), among others, we hypothesize that countries having a higher level of educational attainment will converge to a higher level of freedom and vice versa. To perform our tests, we utilize Barro and Lee's (1996) variable (Education) that measures average years of schooling for persons 25 years of age and over in each country from 1970 to 1990 (the available years).

Natural Resources. The natural resource dependency of a country can be hypothesized to exert both positive and negative effects on political freedoms. Collier and Hoeffler (1998) find that economic dependency on natural resources has a nonlinear impact on the frequency of civil wars. Countries having a larger percentage of natural resource-based exports have a higher probability of civil war-up to $24 \%$ of their total exports, but the probability decreases after that. They hypothesize that natural resources provide rebels with a convenient source of funding for their rebellion. In contrast, at higher shares of natural resources Collier and Hoeffler (1998) suggest that the political climate becomes more stable. In a related hypothesis, Barro (1999) suggests that income derived from natural resources will lead to a monotonically smaller demand for political freedoms than income derived from human and physical capital. Whether there is a nonlinear relation between natural resource dependency and political freedoms is an empirical question, which we examine. We calculate a variable (Natural Resources), as in Sachs and Warner (1995), as the share of primary exports in GDP (using World Bank data). The primary products included in natural resources are SITC categories 0, 1, 4 (foods), 2 (agricultural raw materials), 27, 28, 68 (ores and metals), and 3 (fuels). We use the average over the 198098 period (the available years).

Economic Freedom. Economic freedom is typically measured in terms of security of property rights, freedom of exchange, and personal choice. One of the more prominent measures of national economic freedom is the Fraser Institute's index from 1970 to 1997, measured at approximately five-year intervals (see Gwartney et al. 2000). There is a growing literature on the impact of economic and political freedom on economic growth (see, e.g., Gwartney et al. 1999). One feature that has received recent attention is the relation of economic freedom and political freedom. The evidence for a statistically significant relation between the two is mixed. For example, Farr et al. (1998) find no evidence of a Granger-causal relationship existing in either direction between economic freedom and political freedom. Wu and Davis (1999) find that 
political freedom is independent of economic freedom, given the level of income. However, Dawson (1998) finds that lagged values of civil freedom have a positive impact on economic freedom in the end period and vice versa. Thus we include economic freedom in our models to test for any possible impact of economic freedom on political freedom. Our results may be different due to our use of different variables, such as the variables to capture the effects of differences in legal systems, natural resources, and education.

Other Variables. In addition to legal system, average educational attainment, natural resource dependency, and economic freedom, we examine some other variables that are hypothesized in Barro (1999) to affect political freedoms: in particular, ethnolinguistic diversity, population, per capita real GDP, infant mortality, life expectancy, the urban percent of population, and a dummy variable for membership in the Organization of Petroleum Exporting Countries (OPEC).

\section{TESTING METHODOLOGIES}

\section{Time-Series Tests}

Stochastic Convergence. The null hypothesis that political freedoms are diverging can be examined by testing for a unit root in the logarithm of the ratio of freedom in country i relative to the average of all countries. Stochastic convergence implies that shocks to this log ratio (or the log difference) will be temporary, implying that the log relative series is a stationary process. For example, following a positive (negative) shock, the level of freedom in country i can deviate above (below) the world average only temporarily. In contrast, under the null hypothesis of a unit root the level of freedom is a nonstationary series, implying that country-specific shocks will permanently alter the level of freedom relative to the world. Therefore under the unit root null hypothesis, following a shock there is no tendency to return toward the world average, implying that freedom levels diverge. Because a constant term is included in each test, stochastic convergence is consistent with conditional convergence and country-specific compensating differentials. (4)

To illustrate the stochastic convergence test, let [f.sub.it], denote the natural log of the ratio of freedom in country i relative to the world average level of freedom in year t. Under the null hypothesis of divergence, [f.sub.it] is a nonstationary time-series with a unit root and can be described as follows:

$$
f_{i t}=\mu_{i}+\beta_{i} f_{i t-1}+\varepsilon_{i t}, \quad \varepsilon_{i t} \sim\left(0, \sigma^{2}\right) \quad \text { and }
$$

$$
E\left(\varepsilon_{i i} \varepsilon_{i t-j}\right)=0, j \neq 0,
$$

where [[mu].sub.i] is a country-specific constant term or drift, and [[epsilon].sub.it] is a white noise error term that is independent and identically distributed. A unit root in [f.sub.it], implies that [[beta].sub.i] $=1$. Repeated substitution (given [[beta].sub.i] $=1$ ) of [f.sub.it-1] into (1) gives equation (2) as follows: 


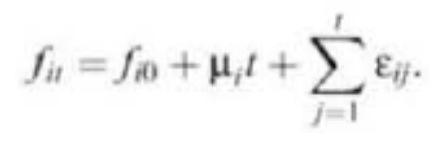

Given (2), a nonstationary [f.sub.it], implies that innovations or shocks ([[epsilon].sub.it]) cause permanent changes in the log relative freedom ratio implying that freedom levels diverge.

Perron (1989) demonstrates that failure to allow for an existing structural break leads to a bias against rejecting a false unit root null hypothesis. To provide a remedy, Perron (1989) proposes to allow for one known, or exogenous, structural break in the augmented Dickey-Fuller (ADF) unit root test. Following Perron (1989), Zivot and Andrews (1992; ZA hereafter), among others, propose to determine the break point endogenously from the data. The ZA test selects the break point where the t-statistic that tests the unit root null is minimized (i.e., the most negative) and therefore least favorable to the unit root hypothesis.

A potential problem common to the ZA and other similar ADF-type endogenous break unit root tests is that they derive their critical values while assuming no break(s) under the null. Nunes et al. (1997) show that this assumption leads to size distortions in the presence of a unit root with break. Lee and Strazicich (2001) further investigate this issue and discover the source of the size distortions. In the presence of a unit root with break, the ZA and similar ADF-type tests tend to select the break point where bias in estimation of the coefficient that tests for a unit root is the greatest. Lumsdaine and Papell (1997; LP hereafter) extend the ZA test to allow for two breaks in level and trend. Lee and Strazicich (2003) demonstrate that in the presence of a unit root with breaks the same outcome occurs as in the ZA test; that is, the LP test tends to estimate the break points where bias and size distortions are the greatest. As a result, when utilizing the ADF-type endogenous breaks tests, researchers can be misled to conclude that a time series is trend stationary when in fact the series is nonstationary with break(s). In this regard, a spurious rejection may result.

To avoid problems of bias and spurious rejections, we utilize the endogenous two-break minimum Lagrange multiplier (LM) unit root test derived in Lee and Strazicich (2003). Contrary to the previously developed endogenous break unit root tests, size properties of the minimum LM test are unaffected by breaks under the null. Thus results using the LM test are more reliable because rejection of the null unambiguously implies a trend stationary series and, hence, stochastic convergence.

Implementation of the two-break minimum LM unit root can be described as follows. According to the LM (score) principle, a unit root test statistic can be obtained from the following regression:

$$
\Delta y_{t}=\delta^{\prime} \Delta Z_{t}+\phi \tilde{S}_{t-1}+\Sigma \gamma_{i} \Delta \tilde{S}_{t-i}+\varepsilon_{t},
$$

where [S.sub.t] is a detrended series such that [S.sub.t] $=[y$. sub.t] $-[[$ psi].sub.x $]$ -

[Z.sub.t][delta], $t=2, \ldots \mathrm{T}$. [delta] is a vector of coefficients in the regression of [DELTA][y.sub.t] on [DELTA][Z.sub.t] and [[psi].sub.x] = [y.sub.1] - [Z.sub.1][delta], where [Z.sub.t] is defined below; [y.sub.1] and [Z.sub.1] are the first observations of [y.sub.t] and [Z.sub.t], respectively; 
and $\mathrm{A}$ is the difference operator, $\mathrm{g}$, is the contemporaneous error term and is assumed independent and identically distributed with zero mean and finite variance. To correct for serial correlation, [DELTA][S.sub.t-1], i = 1, .. k, terms are included as necessary. [Z.sub.t] is a vector of exogenous variables defined by the data generating process. Similar to Perron's (1989) "crash" model A, [Z.sub.t] is described by [1, t, [D.sub.1t], [D.sub.2t]]', where [D.sub.jt] = 1 for $t$ [is greater than or equal to] [T.sub.Bj] $+1, j=1,2$, and 0 otherwise, and [T.sub.Bj] stands for the time period of the breaks. For the two-break equivalent of Perron's (1989) model C, with two changes in level and trend, [Z.sub.t] is described by [1, t, [D.sub.1t], [D.sub.2t], $\mathrm{D}\left[\mathrm{T}\right.$.sup. *.sub.1t], D[T.sup. *.sub.2t]]', where $\mathrm{D}\left[\mathrm{T}\right.$.sup. ${ }^{*}$.sub.jt] = $\mathrm{t}-$ [T.sub.Bj] for $\mathrm{t}$ [is greater than or equal to] [T.sub.Bj] $+1, j=1,2$, and 0 otherwise. Note that test regression (3) involves [DELTA][Z.sub.t] instead of [Z.sub.t], so that [DELTA][Z.sub.t] becomes [1, [B.sub.1t], [B.sub.2t], [D.sub.1t], [D.sub.2t]]' for model C, where [B.sub.jt] = [DELTA][D.sub.jt] and [D.sub.jt] = [DELTA]D[T.sup. *.sub.jt], $j=1,2$. Under the unit root null hypothesis [phi] $=0$ in equation (3), the test statistic can be defined as follows:

$$
\bar{\tau}=t \text {-statistic for the null hypothesis } \phi=0 \text {. }
$$

To endogenously determine the location of two breaks ([[lambda].sub.j] $=[$ T.sub.Bj]/T, j = 1, 2), the minimum LM unit root test uses a grid search as follows:

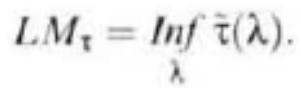

As shown in Lee and Strazicich (2003), critical values for model A are invariant to the size and location of breaks. However, critical values for model $\mathrm{C}$ depend (somewhat) on the location of the breaks ([[lambda].sub.j]). Therefore, for model $\mathrm{C}$ we use critical values that correspond to the location of the breaks.

To implement our test, we first need to determine the number of augmentation terms [DELTA][S.sub.t-i], $\mathrm{i}=1, \ldots \mathrm{k}$, that correct for serial correlation in equation (3). At each combination of break points [lambda] $=([[$ lambda].sub.1], [[lambda].sub.2])' in the time interval $[0.1 \mathrm{~T}, 0.9 \mathrm{~T}]$ (to eliminate end points), where $\mathrm{T}$ is the sample size, we determine $\mathrm{k}$ by following the general to specific procedure suggested by Perron (1989). We begin with a maximum number of lagged first-differenced terms (maximum $\mathrm{k}=8$ ) and examine the last term to see if it is significantly different from zero at the $10 \%$ level (critical value in an asymptotic normal distribution is 1.645). If insignificant, the maximum lagged term is dropped and the model reestimated with $\mathrm{k}=7$ terms and so on, until either the maximum term is found or $\mathrm{k}=0$, at which point the procedure stops. This technique has been shown to perform well as compared to other data-dependent procedures to select the number of lagged augmented terms (see, e.g., Ng and Perron 1995).

We begin our tests for stochastic convergence by employing the minimum two-break LM unit root test. After identifying two breaks in level and trend for each country (model C) we examine the significance of each break term at the $10 \%$ level in an asymptotic normal distribution (i.e., critical value is 1.645). If two break years are not significant, we perform another unit root test, this time using the one-break minimum LM unit root test of Lee and Strazicich (1999). (5) If no 
break is significant at the $10 \%$ level in the one-break test, we utilize the conventional (no-break) ADF test. Thus in addition to endogenously determining the optimal number of augmented terms and the location of the break(s), we endogenously determine the number of breaks for each country. (6)

[beta]-Convergence. Results utilizing cross-section tests for [beta]-convergence have been widely criticized in the literature (see, e.g., Friedman 1992; Quah 1993; Evans 1996; Evans and Karras 1996). Carlino and Mills (1993) suggest an alternative time series test for [beta]convergence. If per capita incomes are converging, then regression of the log relative income on an intercept and trend should find opposite signs on their estimated coefficients. For example, if a country has an initial income above the mean of the world, then the rate of growth of income should be negative for convergence to occur. As noted by Carlino and Mills (1993), because this test does not include the initial level of income on the right-hand side it is not subject to the problems of bias that can result using a cross-section test. Given that we identify structural breaks in level and trend for most countries in our unit root tests, we wish to use this information in our time series tests for [beta]-convergence, Our testing methodology can be described as follows. After performing unit root tests on the log of relative freedom as described above, we identify those countries that reject the unit root null hypothesis (at the $10 \%$ level of significance). These time series can be described as stationary (or trend stationary) around (in most cases) one or two structural breaks in level and trend. We perform ordinary least squares regressions on the log relative income series ( $\mathrm{f} 3$ for each of these time series as follows:

$$
\begin{aligned}
f_{t}= & \mu_{1} D 1_{t}+\mu_{2} D 2_{t}+\mu_{3} D 3_{t}+\gamma_{1} T I M E 1_{t} \\
& +\gamma_{2} \text { TIME } 2_{t}+\gamma_{3} \text { TIME } 3_{t}+\varepsilon_{t},
\end{aligned}
$$

where D[1.sub.t], D[2.sub.t], and D[3.sub.t] are intercept dummy variables and TIME[1.sub.t], TIME[2.sub.t], and TIME[3.sub.t] are linear time trends. D[1.sub.t] = 1 if $t$ [is less than or equal to] [T.sub.B1], and 0 otherwise; $D[2$. sub.t] $=1$ if [T.sub.B1] $<t$ [is less than or equal to] [T.sub.B2], and 0 otherwise; and $\mathrm{D}[3$. sub.t] $=1$ if $t>$ [T.sub.B2], and 0 otherwise. TIME[1.sub.t] $=\mathrm{t}$ if $\mathrm{t}$ [is less than or equal to] [T.sub.B1], and 0 otherwise; TIME[2.sub.t $=\mathrm{t}-$ [T.sub.B1] if [T.sub.B1] < $<$ [T.sub.B2], and 0 otherwise; and TIME[3.sub.t] = $t$ - [T.sub.B2] if $t>$ [T.sub.B2], and 0 otherwise. [[mu].sub.1], [[mu].sub.2], and [[mu].sub.3] denote whether the level of freedom in the country is above (+) or below (-) the average level of freedom prior to the first break, following the first break, and following the second break, respectively. [[gamma].sub.1], [[gamma].sub.2], and [[gamma].sub.3] denote the growth rate of relative freedom over these same time periods, respectively. Because we are interested in the most recent time period to determine if freedoms are converging, we will compare the signs of the estimated coefficients and [[gamma].sub.3]. If the level of freedom in country $i$ is converging to the mean, then [[mu].sub.3] and [[gamma].sub.3] will be of opposite signs. (7) For countries with only one significant break, equation (6) would be estimated without the D[3.sub.t] and TIME[3.sub.t] terms, and convergence would imply opposite signs on [[mu].sub.2] and [[gamma].sub.2]. For countries with no significant breaks, equation (6) would be estimated with only D[1.sub.t] and TIME[1.sub.t], and convergence would imply opposite signs on [[mu].sub.1] and [[gamma].sub.1]. 


\section{FIGURE 1}

Coefficient of Variation in Political

Freedom for 136 Countries 1972-2001

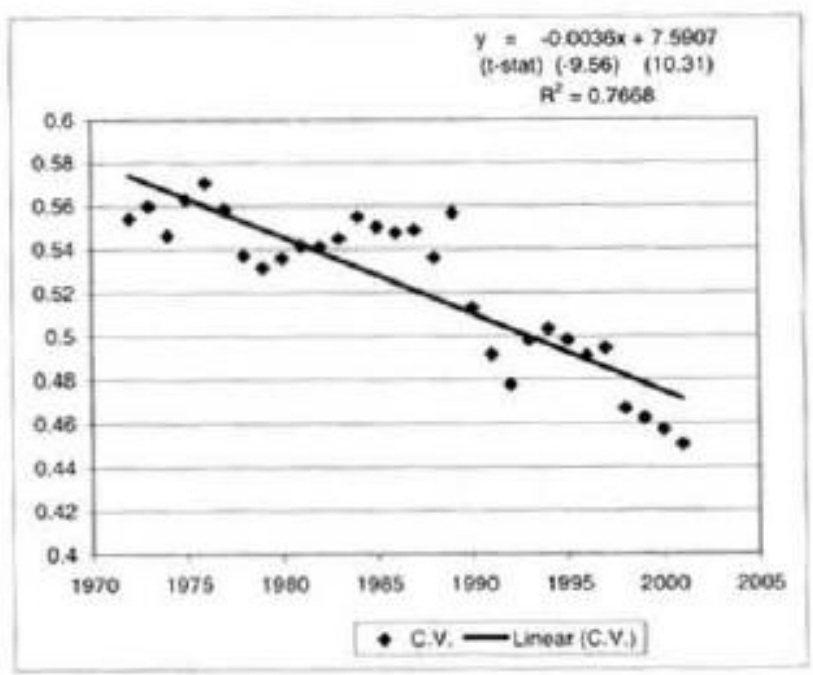

\section{Cross-Section Model of the Determinants of Freedom}

The level of freedom at a given point in time may be impacted by several variables. As described in section III, these variables may include the legal system, average years of educational attainment, natural resource dependency, economic freedom, and some additional variables described in Barro (1999). Because we expect that political freedom in 2001 would be determined by the lagged impact of these variables, we use the average values of the variables over several decades. Natural resources is defined as the 1980-98 average share of primary exports in GDP. Education is the 1970-90 average number of years of schooling of persons 25 years and older. Economic freedom is the 1970-97 average value of the Fraser Institute's measure of economic freedom. The cross-section equation to be estimated can be described as follows:

$$
\begin{aligned}
F_{i, 2001}= & \alpha+\beta_{1} \text { Common (or Common Strict) } \\
& +\beta_{2} \text { Muslim Any (or Muslim Strict) } \\
& +\beta_{3} \text { Natural Resources } \\
& +\beta_{4} \text { Education } \\
& +\beta_{5} \text { Economic Freedom } \\
& \left.+\beta_{6} \text { (other variables one at a time }\right)+\varepsilon_{i} .
\end{aligned}
$$

Because the level of freedom has an upper bound of 14 and lower bound of 2, a two-limit Tobit estimation procedure is used. This limit problem appears to have been ignored in previous studies that estimate the determinants of political freedom. Both the estimated coefficients and the marginal effects are presented. 


\section{EMPIRICAL RESULTS}

\section{Time-Series Results}

As previously noted, Friedman (1992) comments that Hotelling (1933) suggests that "a consistent diminution of variance ... among individual" countries is the real test of convergence. In Figure 1 we show the time path of the coefficient of variation of political freedom for 136 countries from 1972 to 2001 . A simple linear regression indicates that the coefficient on the trend term is negative and highly significant. This is one crude indication that convergence is occurring. We now discuss our main time-series results.

In the unit root tests, the dependent variable is the log of freedom in country i relative to the world mean. Although this variable is not strictly bounded, for countries at the maximum this variable would only change as the world mean changes. Thus we do not include countries that are at the maximum level of freedom in every year or nearly always at the maximum. (8) We initially examine results in Table 1 of undertaking single country conventional ADF unit root tests (without breaks) for stochastic convergence in 118 countries. Overall, the null hypothesis of a unit root and divergence is rejected in 37 out of 118 countries (31\%) at the $10 \%$ level of significance. Although these results are significant in their support for convergence given the low power of ADF tests, we wish to determine if more rejections of the null are possible once structural breaks are allowed. The results of employing the minimum LM unit root test are displayed in Table 2. After allowing for structural breaks, the null of divergence is rejected in 70 countries out of 118 (59\%). These results are impressive given the low power of unit root tests in general and demonstrate the significance of allowing for structural breaks. Overall, the findings of Table 2 provide evidence that freedom levels are stochastically converging for most countries. 
TABLE 1

Individual ADF Unit Root Tests for Stochastic Convergence 1972-2001

\begin{tabular}{|c|c|c|c|c|c|}
\hline Country & $t$-Statistic & Country & t-Statistic & Country & $t$-Statistic \\
\hline Afghanistan & -2.47 & Greece & $-5.00^{3}$ & Nigeria & $-3.48^{c}$ \\
\hline Albania & -2.35 & Guatemala & $-4.83^{a}$ & Oman & -2.87 \\
\hline Algeria & $-3.71^{b}$ & Guinea & -2.55 & Pakistan & -1.84 \\
\hline Argentina & -2.90 & Guyana & -1.73 & Panama & -3.09 \\
\hline Bahrain & -2.86 & Haiti & $-3.92^{b}$ & Paraguay & -3.03 \\
\hline Bangladesh & $-4.55^{a}$ & Honduras & -1.67 & Peru & -2.46 \\
\hline Benin & -2.81 & Hungary & -2.10 & Philippines & -1.61 \\
\hline Bhutan & -2.83 & India & $-3.35^{c}$ & Poland & -1.98 \\
\hline Bolivia & $-3.94^{b}$ & Indonesia & $-4.04^{b}$ & Portugal & $-3.31^{c}$ \\
\hline Botswana & $-5.50^{\mathrm{a}}$ & Iran & -2.23 & Qatar & -2.54 \\
\hline Brazil & -2.01 & Iraq & $-3.70^{b}$ & Romania & -1.41 \\
\hline Brunei & -3.19 & Israel & -2.35 & Rwanda & $-3.92^{b}$ \\
\hline Bulgaria & -1.89 & Italy & -2.06 & Samoa & $-4.04^{b}$ \\
\hline Burkina Faso & -1.81 & Jamaica & -2.61 & Saudi Arabia & -2.77 \\
\hline Burma & -0.48 & Japan & -1.93 & Senegal & -2.85 \\
\hline Burundi & $-3.86^{b}$ & Jordan & -1.86 & Sierra Leone & $-3.40^{\circ}$ \\
\hline Cambodia & -2.52 & Kenya & -2.47 & Singapore & -1.66 \\
\hline Cameroon & -2.87 & Korea (South) & $-2.8 \mathrm{I}$ & Somalia & -1.19 \\
\hline C. African Rep. & -2.13 & Kuwait & $-3.62^{b}$ & South Africa & -2.93 \\
\hline Chad & -2.19 & Laos & -2.36 & Spain & $-10.63^{a}$ \\
\hline Chile & $-7.06^{\mathrm{a}}$ & Lebanon & -2.92 & Sri Lanka & -2.52 \\
\hline China & -1.90 & Lesotho & -2.61 & Sudan & -2.33 \\
\hline Columbia & -2.27 & Liberia & $-3.93^{b}$ & Swaziland & $-7.29^{a}$ \\
\hline Congo Brazzaville & $-3.82^{b}$ & Libya & -1.92 & Syria & -2.98 \\
\hline Congo Kinshasa & $-3.78^{b}$ & Madagascar & -2.75 & Taiwan & $-4.05^{b}$ \\
\hline Cote d'Ivoire & $-3.36^{6}$ & Malawi & -2.17 & Tanzania & 3.72 \\
\hline Cuba & -1.95 & Malaysia & $-3.42^{\mathrm{c}}$ & Thailand & $-4.55^{a}$ \\
\hline Cyprus & $-8.64^{a}$ & Maldives & -1.51 & Togo & $-3.73^{\mathrm{b}}$ \\
\hline Dominican Rep. & $-4.61^{a}$ & Mali & -2.26 & Tonga & -2.94 \\
\hline Ecuador & $-10.3 !^{i}$ & Malta & -2.96 & Trinidad Tobago & 1.20 \\
\hline Egypt & -1.48 & Mauritania & -0.13 & Tunisia & -1.38 \\
\hline EI Salvador & $-3.93^{b}$ & Mauritius & $-4.84^{a}$ & Turkey & $-3.29^{c}$ \\
\hline Equatorial Guinea & -2.14 & Mexico & -2.74 & Uganda & -1.89 \\
\hline Ethiopia & -2.28 & Mongolia & -1.81 & United Arab Emir. & $-3.89^{b}$ \\
\hline Fiji & -2.80 & Morocco & $-3.39^{c}$ & Uruguay & -2.50 \\
\hline Finland & -2.50 & Nauru & -0.75 & Venezuela & -1.26 \\
\hline France & $-4.46^{\prime \prime}$ & Nepal & -1.33 & Yugoslavia & -1.86 \\
\hline Gabon & -2.64 & Nicaragua & -3.14 & Zambia & -2.57 \\
\hline Gambia & -2.17 & Niger & -2.13 & Zimbabwe & -2.10 \\
\hline Ghana & -1.68 & & & & \\
\hline
\end{tabular}

Notes: The dependent variable is the natural $\log$ of the ratio of the political freedom index for country $i$ in year $t$ divided by the average political freedom index of all 118 countries in year $t$. The $t$-statistic tests the null hypothesis of a unit root. Rejection of the null hypothesis supports stochastic convergence. All unit root tests were performed with an intercept and linear time trend, ${ }^{a}, b$, and ' denote significance at the $1 \%, 5 \%$, and $10 \%$ levels, respectively. Critical values come from MacKinnon (1991). 
TABLE 2

LM Unit Root Tests for Stochastic Convergence 1972-2001

\begin{tabular}{|c|c|c|c|c|c|c|c|c|}
\hline Country & 1-Statistic & Breaks & Country & $t$-Statistic & Breaks & Country & t-Statistic & Breaks \\
\hline Afghanistan & $-3.63^{b}$ & 87 & Greece & -1.76 & 82,88 & Nigeria & $-3.48^{\mathrm{C}}$ & \\
\hline Albania & $-3.63^{c}$ & 90,92 & Guatemala & $-4.52^{b}$ & 85,95 & Oman & -2.68 & 92 \\
\hline Algeria & $-5.79^{n}$ & 90,96 & Guinea & -2.58 & 83 & Pakistan & -3.10 & 84,87 \\
\hline Argentina & $-5.91^{3}$ & 83 & Guyana & -1.73 & & Panama & $-5.85^{a}$ & 96 \\
\hline Bahrain & $-4.28^{n}$ & 88 & Haiti & $-5.53^{\mathrm{a}}$ & 84,92 & Paraguay & -3.03 & \\
\hline Bangladesh & $-5.16^{a}$ & 84.90 & Honduras & -1.67 & & Peru & $-3.5 \mathrm{I}^{\mathrm{c}}$ & 84.91 \\
\hline Benin & -3.19 & & Hungary & -2.71 & 89 & Philippines & $-4.73^{*}$ & 84,86 \\
\hline Bhutan & -3.13 & 82,91 & India & -2.44 & 90 & Poland & $-4.17^{b}$ & 88,94 \\
\hline Bolivia & $-11.41^{2}$ & 87 & Indonesia & $-4.04^{b}$ & & Portugal & -1.05 & 90.92 \\
\hline Botswana & -2.61 & 92 & Iran & $-4.71^{a}$ & 88,91 & Qatar & -3.06 & 88 \\
\hline Brazil & $-4.00^{6}$ & 83.89 & Iraq & $-3.70^{b}$ & & Romania & $-3,44^{c}$ & 89 \\
\hline Brunei & $-4.48^{b}$ & 87.93 & Israel & -3.38 & 89.97 & Rwanda & $-3.92^{b}$ & \\
\hline Bulgaria & $-4.51^{b}$ & 89.92 & Italy & $-4.12^{b}$ & 93 & Samoa & $-4.38^{b}$ & 88,98 \\
\hline Burkina Faso & $-6.11^{\circ}$ & 88,91 & Jamaica & $-6.62^{3}$ & 85 & Saudi Arabia & -2.25 & 82,91 \\
\hline Burma & $-5.10^{\alpha}$ & 86,93 & Japan & -3.18 & 83 & Senegal & -1.69 & 82,92 \\
\hline Burundi & $-3.86^{b}$ & & Jordan & $-4.04^{b}$ & 87 & Sierra Leone & $-4.75^{\prime \prime}$ & 95 \\
\hline Cambodia & -2.59 & 96 & Kenya & $-3.53^{c}$ & 86 & Singapore & $-4.64^{4}$ & 96 \\
\hline Cameroon & $-4.33^{b}$ & 84.91 & Korea (South) & $-3.24^{\circ}$ & 82 & Somalia & -2.50 & 82 \\
\hline C. African Rep. & $-3.39^{6}$ & 97 & Kuwait & $-4.80^{4}$ & 85 & South Africa & -2.15 & 84 \\
\hline Chad & $-5.55^{4}$ & 86,95 & Laos & -2.52 & 87 & Spain & $-4.71^{4}$ & 85,88 \\
\hline Chile & $-7.06^{a}$ & & Lebanon & $-3.40^{c}$ & 91 & Sri Lanka & -2.52 & \\
\hline China & -2.37 & 88,97 & Lesotho & $-3.21^{c}$ & 87 & Sudan & $-5.81^{7}$ & 85,88 \\
\hline Columbia & $-3.88^{b}$ & 88,98 & Liberia & $-3.46^{c}$ & 89 & Swaziland & $-7.29^{\circ}$ & \\
\hline Congo Brazzavil & $-3.82^{b}$ & & Libya & -1.92 & & Syria & -3.15 & 83.88 \\
\hline Congo Kinshasa & $-4.54^{3}$ & 84 & Madagascar & $-6.13^{4}$ & 88,92 & Taiwan & $-4.05^{b}$ & \\
\hline Cóte d'Ivoire & -2.96 & 89.91 & Malawi & -2.61 & 93 & Tanzania & $-4.35^{b}$ & 83,98 \\
\hline Cuba & -1.95 & & Malaysia & $-4.69^{a}$ & 89 & Thailand & $-4.78^{a}$ & 90 \\
\hline Cyprus & $-8.64^{i n}$ & & Maldives & $-4.02^{b}$ & 82,85 & Togo & -3.04 & 83,93 \\
\hline Dominican Rep. & $-6.85^{a}$ & 95 & Mali & -1.99 & 87.91 & Tonga & -2.94 & \\
\hline Ecuador & -1.33 & 87 & Malta & $-4.75^{a}$ & 86.92 & Trinidad Tobago & 1.20 & \\
\hline Egypt & -1.48 & & Mauritania & $-3,26$ & 89.98 & Tunisia & $-4.05^{b}$ & 90 \\
\hline El Salvador & $-4.13^{b}$ & 91 & Mauritius & $-5.58^{a}$ & 93 & Turkey & $-8.38^{\prime \prime}$ & 93 \\
\hline Equat. Guinea & -2.14 & & Mexico & $-3.63^{b}$ & 87 & Uganda & -1.89 & \\
\hline Ethiopiat & -3.12 & 88 & Mongolia & -1.81 & & United Arab Em. & -2.84 & 97 \\
\hline $\mathrm{Fiji}$ & $-4.95^{\mathrm{a}}$ & 86 & Morccco & $-3.93^{b}$ & 91 & Uruguay & $-8.19^{\circ}$ & 83,89 \\
\hline Finland & $-5.05^{a}$ & 90 & Nauru & -0.75 & & Venezuela & $-3.35^{\mathrm{c}}$ & 91 \\
\hline France & $-4.46^{2}$ & & Nepal & -3.46 & 90,94 & Yugoslavia & -3.14 & 87 \\
\hline Gabon & -3.67 & 89,93 & Nicaragua & $-4.58^{3}$ & 86.89 & Zambia & -2.98 & 90 \\
\hline Gambia & -2.17 & & Niger & $-6.15^{a}$ & 89.94 & Zimbabwe & -2.10 & \\
\hline Ghana & -2.46 & 83 & & & & & & \\
\hline
\end{tabular}

Notes: The dependent variable is the natural log of the ratio of political freedom for country $i$ in year $t$ divided by the average political freedom index of all 118 countries in year $t .1$-statistic tests the null hypothesis of a unit root. Rejection of the null hypothesis supports stochastic convergence. All unit root tests include intercept(s) and trend(s). Breaks denote the break years that were identified by the one- or two-break minimum LM unit root test (the 19-prefix is omitted to conserve space). A blank space denotes no breaks were significant at the $10 \%$ level. In the case of no significant breaks. the results were obtained using the conventional ADF test and copied from Table $1,{ }^{a, b}$, and ${ }^{c}$ denote significance at the $1 \%, 5 \%$, and $10 \%$ levels, respectively. Critical values for the one- and two-break minimum LM test come from Lee and Strazicich (1999: 2003). 
TABLE 3

Summary of Time-Series Test Results for Convergence 1972-2001

\begin{tabular}{|c|c|c|c|c|c|}
\hline Country & Converging? & Country & Converging? & Country & Converging? \\
\hline Afghanistan & D & Greece & $\mathrm{U}$ & Nigeria & c \\
\hline Albania & C & Guatemala & $\mathbf{E}$ & Oman & U \\
\hline Algeria & c & Guinea & $\mathbf{U}$ & Pakistan & $\mathbf{U}$ \\
\hline Argentina & C & Guyana & $\mathrm{U}$ & Panama & $\mathrm{E}$ \\
\hline Bahrain & D & Haiti & c & Paraguay & $\mathrm{U}$ \\
\hline Bangladesh & c & Honduras & $\mathrm{U}$ & Peru & C \\
\hline Benin & $\mathrm{U}$ & Hungary & U & Philippines & $\mathrm{C}$ \\
\hline Bhutan & $\mathrm{U}$ & India & U & Poland & $\mathrm{c}$ \\
\hline Bolivia & c & Indonesia & d & Portugal & $\mathbf{U}$ \\
\hline Botswana & $\mathrm{U}$ & Iran & c & Qatar & $\mathbf{U}$ \\
\hline Brazil & C & Iraq & D & Romania & C \\
\hline Brunei & c & Israel & U & Rwanda & D \\
\hline Bulgaria & C & Italy & c & Samoa & $\mathrm{c}$ \\
\hline Burkina Faso & E & Jamaica & C & Saudi Arabia & $\mathrm{U}$ \\
\hline Burma & d & Japan & $\mathrm{U}$ & Senegal & $\mathbf{U}$ \\
\hline Burundi & d & Jordan & $\mathbf{E}$ & Sierra Leone & c \\
\hline Cambodia & $\mathrm{U}$ & Kenya & d & Singapore & d \\
\hline Cameroon & d & Korea (South) & d & Somalia & $\mathbf{U}$ \\
\hline C. African Rep. & $\mathrm{E}$ & Kuwait & C & South Africa & U \\
\hline Chad & d & Laos & $\mathbf{U}$ & Spain & $\mathrm{C}$ \\
\hline Chile & $\mathrm{C}$ & Lebanon & D & Sri Lanka & $\mathbf{U}$ \\
\hline China & $\mathrm{U}$ & Lesotho & $\mathrm{C}$ & Sudan & d \\
\hline Columbia & $\mathrm{E}$ & Liberia & C & Swaziland & c \\
\hline Congo Brazzaville & $\mathrm{C}$ & Libya & $\mathbf{U}$ & Syria & $\mathbf{U}$ \\
\hline Congo Kinshasa & c & Madagascar & c & Taiwan & C \\
\hline Còte d'Ivoire & U & Malawi & $\mathbf{U}$ & Tanzania & $\mathrm{E}$ \\
\hline Cuba & U & Malaysia & c & Thailand & c \\
\hline Cyprus & D & Maldives & D & Togo & $\mathrm{U}$ \\
\hline Dominican Rep. & D & Mali & $\mathbf{U}$ & Tonga & $\mathrm{U}$ \\
\hline Ecuador & U & Malta & C & Trinidad Tobago & $\mathrm{U}$ \\
\hline Egypt & $\mathrm{U}$ & Mauritania & $\mathbf{U}$ & Tunisia & D \\
\hline El Salvador & d & Mauritius & c & Turkey & E \\
\hline Equat. Guinea & $\mathrm{U}$ & Mexico & d & Uganda & $\mathbf{U}$ \\
\hline Ethiopia & $\mathrm{U}$ & Mongolia & $\mathbf{U}$ & United Arab Em. & U \\
\hline Fiji & C & Morocco & c & Uruguay & d \\
\hline Finland & C & Nauru & $\mathbf{U}$ & Venezuela & c \\
\hline France & $\mathrm{C}$ & Nepal & $\mathbf{U}$ & Yugoslavia & $\mathrm{U}$ \\
\hline Gabon & d & Nicaragua & d & Zambia & $\mathbf{U}$ \\
\hline Gambia & U & Niger & c & Zimbabwe & $\mathbf{u}$ \\
\hline Ghana & $\mathrm{U}$ & & & & \\
\hline
\end{tabular}

Notes: To be considered as converging, the time series of $\log$ relative political freedom for country $i$ must satisfy the following criteria. First, the time series must reject the null hypothesis of a unit root, implying that political freedoms are not diverging. Next, for those countries that reject the unit root null hypothesis (at the $10 \%$ level of significance), a simple OLS regression on the intercept(s) and trend(s) was performed that includes structural breaks identified using the minimum LM unit root test. Finally, the coefficients on intercept and trend in the time period following the final break must be of opposite sign. The implication of the significance of these coefficients is deseribed as follows. C denotes point estimates consistent with $\beta$-convergence that are statistically significant at least at the $10 \%$ level. $c$ denotes point estimates consistent with $\beta$-convergence with only one estimate statistically significant at least at the $10 \%$ level. D denotes point estimates consistent with divergence that are statistically significant at least at the $10 \%$ level. d denotes point estimates consistent with divergence with only one estimate statistically significant at least at the $10 \%$ level. $U$ denotes unit root, which implies that the null hypothesis of divergence cannot be rejected. E denotes point estimates very small in magnitude and statistically insignificant, which suggest that convergence has occurred. Therefore, C, c, and E denote evidence of convergenee, and D, d, and $U$ imply that divergence cannot be rejected. 
We next examine the results of testing the time series notion of [beta]-convergence as displayed in Table 3. We follow the notation of Tomljanovich and Vogelsang (2002) and identify our findings as follows. $\mathrm{C}$ denotes opposite signs on the intercept and the trend coefficients with both being significant at the $10 \%$ level. Thus, $\mathrm{C}$ denotes the strongest evidence for convergence, $c$ denotes opposite signs on the intercept and the trend coefficients, with only one coefficient significant at the $10 \%$ level. D denotes that although the intercept and trend coefficients are both significant at the $10 \%$ level, they are of the same sign, implying that freedom is diverging, $d$ denotes that coefficients on the intercept and trend are of the same sign, implying divergence, but only one coefficient is significant at the $10 \%$ level. E denotes that neither the intercept nor trend coefficient is significant at the $10 \%$ level. However, given that the unit root null hypothesis was rejected for this country in Table 2, this indicates that the level of freedom has converged to the world mean and [beta]-convergence has occurred. (9) $U$ indicates that the null hypothesis of a unit root could not be rejected in Table 2, implying that divergence could not be rejected. Therefore, a notation of $\mathrm{C}$, c, or $\mathrm{E}$ supports convergence of freedom to the world, and $D, d$, and $U$ imply that the level of freedom is diverging. Overall, the results presented in Table 3 suggest that freedom levels are converging to the average in 47 out of 118 countries (40\%). We omitted 17 countries that were at the maximum in all years (or nearly so); combined with the fact that the average level of freedom in the world has been increasing, this suggests that 64 out of 136 countries (47\%) have freedom levels that support convergence. Overall, the results provide evidence that political freedoms are converging for nearly half of the nations of the world. However, these findings also suggest that about half of the countries in the world have political freedom levels that are not converging. To search for an explanation as to why freedom levels are higher in some countries and not in others we examine our cross-section test results of factors that determine freedom.

\section{Cross-Section Results}

Cross-section results for equation (7) are shown in Tables 4 and 5. The two-limit Tobit results for the models that use the Muslim Any dummy are shown in Table 4. In all five models the coefficient on the Muslim Any dummy is negative and significant, indicating that there is less freedom in countries that have some Muslim law, in comparison to civil law countries. The Common dummy's coefficient is positive and significant only in model 2, which includes Economic Freedom. This provides only weak support for Hayek's (1973) hypothesis that common law countries will provide the highest levels of freedom. In model 2, Economic Freedom's coefficient is positive and highly significant. In model 3, average years of educational attainment (Education) is positive and highly significant. This result suggests that countries having a higher level of education tend to have a higher level of freedom and vice versa. In model 4, Natural Resources dependency has a negative impact on freedom. 
TABLE 4

Tobit Results for Freedom Levels in 2001 with any Muslim Law

\begin{tabular}{|c|c|c|c|c|c|}
\hline Variable & Model 1 & Model 2 & Model 3 & Model 4 & Model 5 \\
\hline Constant & $\begin{array}{l}10.55 \\
(0.49)^{\prime \prime} \\
{[9.11]}\end{array}$ & $\begin{array}{r}-1.34 \\
(1.36) \\
{[-1.22]}\end{array}$ & $\begin{array}{l}6.05 \\
(0.63)^{\mathrm{n}} \\
{[5.74]}\end{array}$ & $\begin{array}{l}11.57 \\
(0.61)^{n} \\
{[10.11]}\end{array}$ & $\begin{array}{l}3.23 \\
(1.47)^{b} \\
{[3.04]}\end{array}$ \\
\hline Common & $\begin{array}{c}0.03 \\
(0.86) \\
{[0.02]}\end{array}$ & $\begin{array}{l}2.64 \\
(0.45)^{a} \\
{[2.40]}\end{array}$ & $\begin{array}{r}-0.77 \\
(0.68) \\
{[-0.73]}\end{array}$ & $\begin{array}{l}0.56 \\
(0.87) \\
{[0.49]}\end{array}$ & $\begin{array}{c}0.08 \\
(0.68) \\
{[0.76]}\end{array}$ \\
\hline Muslim Any & $\begin{array}{c}-5,92 \\
(0,89)^{a} \\
{[-5,11]}\end{array}$ & $\begin{array}{c}-2.64 \\
(0.45)^{a} \\
{[-2.40]}\end{array}$ & $\begin{array}{c}-4.08 \\
(0.71)^{\mathrm{a}} \\
{[-3.86]}\end{array}$ & $\begin{array}{c}-5.00 \\
(0.92)^{n} \\
{[-4.36]}\end{array}$ & $\begin{array}{c}-3.19 \\
(0.72)^{4} \\
{[-3.01]}\end{array}$ \\
\hline Natural Resources & & & & $\begin{array}{c}-5,81 \\
(2,65)^{b} \\
{[-5,08]}\end{array}$ & $\begin{array}{c}-5.46 \\
(2.14)^{b} \\
{[-5.14]}\end{array}$ \\
\hline Educution & & & $\begin{array}{l}1.16 \\
(0.13)^{a} \\
{[1.10]}\end{array}$ & & $\begin{array}{l}0.73 \\
(0.18)^{2} \\
{[0.69]}\end{array}$ \\
\hline Economic Freedom & & $\begin{array}{l}1.94 \\
(0.23)^{a} \\
{[1.77]}\end{array}$ & & & $\begin{array}{c}0.89 \\
(0.33)^{4} \\
{[0.84]}\end{array}$ \\
\hline$N$ & 123 & 101 & 96 & 105 & 85 \\
\hline Log likelihood & $-294,98$ & -212.71 & -186.86 & -244.64 & -159.26 \\
\hline
\end{tabular}

Notes: The dependent variable is the level of political freedom in country in 2001 . Common is a dummy equal to one if common law is the predominant legal type and no Muslim law is present. Muslim Any is a dummy variable equal to one if any Muslim law is present. The base case is civil law (with no Muslim law). Natural Resources is the $1980-98$ average share of primary exports in GDP. Education is the $1970-90$ average number of years of schooling of persons 25 years and older. Economic Freedom is the 1970-97 average value of the Fraser Institute's measure of economic freedom. $N=$ the number of countries included in the cross-section regression. Standard errors are shown in parentheses beneath the estimated coefficient. The marginal effects are shown in brackets beneath the standard errors. ${ }^{a}, b$ and $c$ denote significance at the $1 \%, 5 \%$, and $10 \%$ levels, respectively.

In model 5 we include all the variables in the model. All of the variables are statistically significant, except Common. As in all other models, the coefficient on the Muslim Any variable is negative and highly significant (at less than the $1 \%$ level). This result suggests that, ceteris paribus, countries with Muslim law will tend to have a lower level of political freedom. Average educational attainment continues to be positively related to political freedoms and remains highly significant (at less than the $1 \%$ level). The Natural Resources variable is also significant. These results demonstrate that the effect of natural resource dependency on the level of political freedom is significant and negative in each specification. However, a Natural Resources squared term was not significant. (10) This latter result is in contrast to what might be expected from the nonlinear findings of Collier and Hoeffler (1998) and is more in line with the hypothesis posited by Barro (1999). Again, Economic Freedom has a positive impact and is statistically significant. 
TABLE 5

Tobit Results for Freedom Levels in 2001 with Strictly Muslim Law

\begin{tabular}{|c|c|c|c|c|c|}
\hline Variable & Model 1 & Model 2 & Model 3 & Model 4 & Model 5 \\
\hline Constant & $\begin{array}{l}9.98 \\
(0.50)^{3} \\
{[8.38]}\end{array}$ & $\begin{array}{r}-1.91 \\
(1.48) \\
{[-1.69]}\end{array}$ & $\begin{array}{l}5.22 \\
(0.63)^{n} \\
{[4.88]}\end{array}$ & $\begin{array}{l}11.31 \\
(0.63)^{a} \\
{[9.65]}\end{array}$ & $\begin{array}{l}3.36 \\
(1.54)^{b} \\
{[3.10]}\end{array}$ \\
\hline Common Strict & $\begin{array}{c}0.14 \\
(0.86) \\
{[0.12]}\end{array}$ & $\begin{array}{l}2.13 \\
(0.55)^{\mathrm{a}} \\
{[1.89]}\end{array}$ & $\begin{array}{r}-0.63 \\
(0.67) \\
{[-0.59]}\end{array}$ & $\begin{array}{c}0.45 \\
(0.86) \\
{[0.38]}\end{array}$ & $\begin{array}{r}-0.17 \\
(0.68) \\
{[-0.16]}\end{array}$ \\
\hline Muslim Strict & $\begin{array}{c}-6.26 \\
(1.16)^{a} \\
{[-5.25]}\end{array}$ & $\begin{array}{c}-2.13 \\
(0.55)^{a} \\
{[-1.89]}\end{array}$ & $\begin{array}{c}-4.42 \\
(0.97)^{a} \\
{[-4.12]}\end{array}$ & $\begin{array}{c}-5.31 \\
(1.21)^{n} \\
{[-4.53]}\end{array}$ & $\begin{array}{c}-3.01 \\
(1.05)^{*} \\
{[-2.78]}\end{array}$ \\
\hline Natural Resources & & & & $\begin{array}{c}-6.87 \\
(2.82)^{b} \\
{[-5.86]}\end{array}$ & $\begin{array}{l}-5.61 \\
(2.35)^{b} \\
{[-5.18]}\end{array}$ \\
\hline Education & & & $\begin{array}{l}1.28 \\
(0.13)^{*} \\
{[1.19]}\end{array}$ & & $\begin{array}{c}0.90 \\
(0.19)^{*} \\
{[0.83]}\end{array}$ \\
\hline Economic Freedom & & $\begin{array}{l}2.00 \\
(0.25)^{\mathrm{a}} \\
{[1.77]}\end{array}$ & & & $\begin{array}{c}0.71 \\
(0.35)^{b} \\
{[0.66]}\end{array}$ \\
\hline N & 123 & 101 & 96 & 105 & 85 \\
\hline Log likelihood & -301.85 & -220.45 & -191.23 & -249.96 & -164.70 \\
\hline
\end{tabular}

Notes: The dependent variable is the level of political freedom in country $i$ in 2001 . Common Strict is a dummy equal to one if common law is predominant. Muslim Strict is a dummy variable equal to one if Muslim law is predominant. The base case is civil law. Natural Resources is the 1980-98 average share of primary exports in GDP. Education is the $1970-90$ average number of years of schooling of persons 25 years and older. Economic Freedom is the $1970-97$ average value of the Fraser Institute's measure of economic freedom. $N=$ the number of countries included in the eross-section regression. Standard errors are shown in parentheses beneath the estimated coefficient. The marginal effects are shown in brackets beneath the standard errors. ${ }^{2}, b$, and ${ }^{c}$ denote significance at the $1 \%, 5 \%$, and $10 \%$ levels, respectively.

Because the Muslim law variable is highly significant in all cases, a further examination of this variable may be warranted. Some of the countries classified as having Muslim law in Table 4 (see Appendix Table A1), though having important characteristics of such, cannot be described as having predominately Muslim law. In particular, Algeria, Egypt, Indonesia, Iraq, Lebanon, and Tunisia can be characterized as having mostly civil law. In addition, The Gambia, India, Kenya, Malaysia, Nigeria, and Singapore can be characterized as having mostly common law. We want to determine if a more strict classification of countries having predominately Muslim law will impact our findings. To check the robustness of our results, we show the two-limit Tobit estimates using these more strict legal classifications in Table 5. (11) Overall, the results in Table 5 are essentially unchanged from those in Table 4. Common Strict's coefficient is only significant in model 2. As in Table 4, the coefficient on predominantly Muslim law (Muslim Strict) remains negative and highly significant (at less than the $1 \%$ level) in all models. Education's coefficient is again positive and highly significant (at less than the $1 \%$ level). Natural Resources's coefficient is again negative and significant. As before, Economic Freedom's coefficient is positive and significant. This result is consistent with Dawson's (1998) findings, but is in contrast to the findings of Farr et al. (1998) and Wu and Davis (1999), who found no significant relationship between economic freedom and political freedom. 
In testing the determinants of democracy, Barro (1999) examines some additional variables that might be hypothesized to impact freedom. To determine if these variables might impact long-run freedom levels, we performed additional regressions by adding some of these variables, as in Barro (1999), one at a time to model 5 of Table 5. (12) The results are displayed in Table 6. None of the additional variables included in Table 6 are significant at the $10 \%$ level. These results are in contrast to Barro (1999), who finds a positive and significant relationship between political freedom and log of per capita GDP. In addition, he finds that log (population) (positive), log (life expectancy) (positive), and infant mortality (negative) are marginally significant, but their significance falls if included with other standard of living variables. One possible explanation for the insignificance of these variables in Table 6 is that most of these variables are correlated with educational attainment. However, it should be noted that when each of the variables in Table 6 is added to model 5 in Table 5, the educational attainment variable remains positive and highly significant (at less than the $1 \%$ level). The other variables from model 5 also remain significant when the variables in Table 6 are included.

TABLE 6

Additional Variables in Tobit Models of Freedom Levels in 2001

\begin{tabular}{lcccc}
\hline Independent Variable & Regression Coefficient & Standard Error & Marginal Effect & Number of Observations \\
\hline Ethno linguistic diversity & -0.71 & 1.14 & -0.66 & 79 \\
Real GDP per capita & $3.05 \cdot 10^{-5}$ & $1.19 \cdot 10^{-4}$ & $2.81 \cdot 10^{-5}$ & 82 \\
Infant mortality rate & 0.021 & 0.014 & 0.019 & 85 \\
Life expectancy & -0.024 & 0.056 & -0.022 & 85 \\
Population & $1.74 \cdot 10^{-9}$ & $3.29 \cdot 10^{-9}$ & $1.60 \cdot 10^{-9}$ & 85 \\
Urbanization rate & -0.027 & 0.019 & -0.025 & 85 \\
OPEC & -1.17 & 1.20 & -1.08 & 85 \\
\hline
\end{tabular}

Notes: The explanatory variables were added one at a time to the regression model estimated in model 5 of Table 5 . The dependent variable is the level of political freedom in country $i$ in $2001 . N=$ the number of countries included in the cross-section regression.

Given that our time-series results show that freedom levels are converging for many countries, it is interesting to examine to where they are converging. Figure 2 shows a time-series plot of the average level of political freedom in the 136 countries examined in this article from 1972-2001. In general, we see that the average level of freedom in the world has been increasing from approximately 7 in 1972 to 9 in 2001 . Given our findings that freedom levels are converging for many countries, the plot displayed in Figure 2 provides some optimism regarding the future course of world freedom. 


\section{FIGURE 2}

Average Level of Political Freedom for

136 Countries 1972-2001

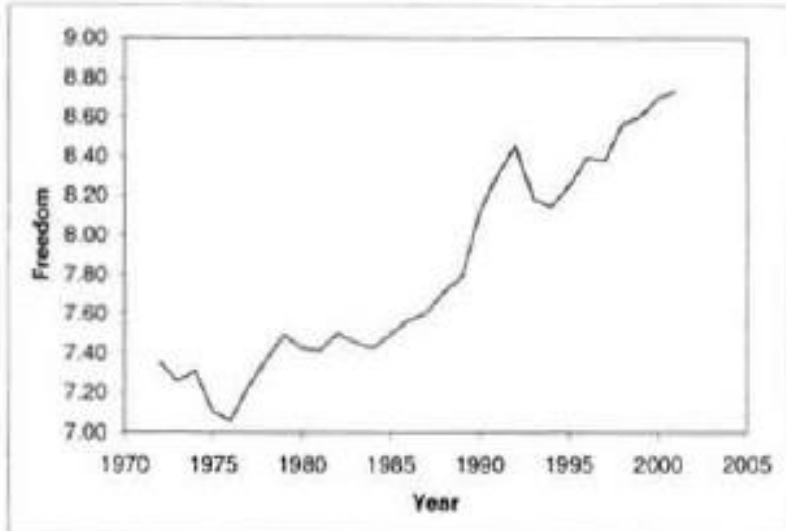

\section{CONCLUSION}

In this article we examined an index of political freedoms in 136 countries from 1972 to 2001 to test if freedom levels are converging. Two types of time-series tests were employed. First, unit root tests that allowed for structural breaks were utilized to test for stochastic convergence. Stochastic convergence implies that shocks to the level of freedom in country i relative to the average of all countries will be temporary, implying that the log of relative freedom is a stationary process. The test results rejected the null of divergence and supported the alternative hypothesis that freedom levels are stochastically converging in 70 of 118 countries. In addition, time series tests for [beta]-convergence were undertaken and indicated that freedom levels are converging among approximately half of the countries.

Given that freedom levels have not completely converged and about half the countries could not reject divergence, we examined in more detail factors hypothesized to affect freedom. To determine the effect of factors that may be positively or negatively related to the level of political freedom, we employed a two-limit Tobit model using the level of freedom in 2001 for a large cross-section of countries. The results of our cross-section tests were highly significant. Political freedom was negatively impacted by Muslim law (compared to civil law) and natural resource dependency, and positively impacted by education and economic freedom. In addition, we found only weak evidence that common law has a positive impact on political freedom (compared to civil law).

Overall, the findings reported herein suggest that national political freedoms are converging for approximately half the countries of the world. However, the time path of political freedom in many countries was unable to reject divergence, and some significant differences in freedom remain. Countries ruled by Muslim law and/or more dependent on natural resources tend to have relatively lower levels of political freedom, whereas countries with greater educational attainment and economic freedom tend to have relatively higher levels of freedom. 


\section{ABBREVIATIONS}

ADF: Augmented Dickey Fuller

GDP: Gross Domestic Product

LM: Lagrange Multiplier

LP: Lumsdaine and Papell

OPEC: Organization of Petroleum Exporting Countries

ZA: Zivot and Andrews

\section{Political Rights}

\begin{tabular}{lc}
\hline Category Number & Raw Points \\
\hline 1 & $28-32$ \\
2 & $23-27$ \\
3 & $19-22$ \\
4 & $14-18$ \\
5 & $10-13$ \\
6 & $5-9$ \\
7 & $0-4$ \\
\hline
\end{tabular}

Civil Liberties

\begin{tabular}{lc}
\hline Category Number & Raw Points \\
\hline 1 & $50-56$ \\
2 & $42-49$ \\
3 & $34-41$ \\
4 & $26-33$ \\
5 & $17-25$ \\
6 & $9-16$ \\
7 & $0-8$ \\
\hline
\end{tabular}

\section{APPENDIX}

\section{Freedom House Political Rights Check List}

1. Is the head of state and/or head of government or other chief authority elected through free and fair elections?

2. Are the legislative representatives elected through free and fair elections?

3. Are there fair electoral laws, equal campaigning opportunities, fair polling, and honest tabulation of ballots?

4. Are the voters able to endow their freely elected representatives with real power?

5. Do the people have the right to organize in different political parties or other competitive political groupings of their choice, and is the system open to the rise and fall of these competing parties or groupings?

6. Is there a significant opposition vote, de facto opposition power, and a realistic possibility for the opposition to increase its support or gain power through elections? 
7. Are the people free from domination by the military, foreign powers, totalitarian parties, religious hierarchies, economic oligarchies, or any other powerful group?

8. Do cultural, ethnic, religious, and other minority groups have reasonable self-determination, self-government, autonomy, or participation through informal consensus in the decision-making process?

\section{Freedom House Civil Liberties Check List}

\section{A. Freedom of Expression and Belief}

1. Are there free and independent media and other forms of cultural expression?

2. Are there free religious institutions and is there free private and public religious expression?

\section{B. Association and Organizational Rights}

1. Is there freedom of assembly, demonstration, and open public discussion?

2. Is there freedom of political or quasi-political organization? Are there free trade unions and peasant organizations or equivalents, and is there effective collective bargaining? Are there free professional and other private organizations?

3. Are there free trade unions and peasant organizations or equivalents, and is there effective collective bargaining? Are there free professional and other private organizations?

\section{Rule of Law and Human Rights}

1. Is there an independent judiciary?

2. Does the rule of law prevail in civil and criminal matters? Is the population treated equally under the law? Are police under direct civilian control?

3. Is there protection from political terror, unjustified imprisonment, exile, or torture, whether by groups that support or oppose the system? Is there freedom from war and insurgencies?

4. Is there freedom from extreme government indifference and corruption?

\section{Personal Autonomy and Economic Rights}

1. Is there open and free private discussion?

2. Is there personal autonomy? Does the state control travel, choice of residence, or choice of employment? Is there freedom from indoctrination and excessive dependency on the state?

3. Are property rights secure'? Do citizens have the right to establish private businesses? Is private business activity unduly influenced by government officials, the security forces, or organized crime? 
4. Are there personal social freedoms, including gender equality, choice of marriage partners, and size of family?

5. Is there equality of opportunity, including freedom from exploitation by or dependency on landlords, employers, union leaders, bureaucrats, or other types of obstacles to a share of legitimate economic gains? 
TABLE AI

Specific Legal Type by Country

\begin{tabular}{|c|c|c|c|c|c|c|c|c|c|c|c|c|c|c|}
\hline Country & $\mathrm{Cl}$ & $\mathrm{C} 2$ & MI & M2 & Country & $\mathrm{Cl}$ & $\mathrm{C} 2$ & MI & M2 & Country & $\mathrm{C} 1$ & $\mathrm{C} 2$ & M1 & M2 \\
\hline Afghanistan & 0 & 0 & 1 & 1 & Greece & 0 & 0 & 0 & 0 & Niger & 0 & 0 & 0 & 0 \\
\hline Algeria & 0 & 0 & 0 & 1 & Guatemala & 0 & 0 & 0 & 0 & Nigeria & 0 & 1 & 0 & 1 \\
\hline Argentina & 0 & 0 & 0 & 0 & Guinea & 0 & 0 & 0 & 0 & Norway & 0 & 0 & 0 & 0 \\
\hline Australia & 1 & 1 & 0 & 0 & Guyana & 1 & 1 & 0 & 0 & Oman & 0 & 0 & 1 & 1 \\
\hline Austria & 0 & 0 & 0 & 0 & Haiti & 0 & 0 & 0 & 0 & Pakistan & 0 & 0 & 1 & 1 \\
\hline Bahrain & 0 & 0 & 1 & 1 & Honduras & 0 & 0 & 0 & 0 & Panama & 0 & 0 & 0 & 0 \\
\hline Bangladesh & 0 & 0 & 1 & 1 & Iceland & 0 & 0 & 0 & 0 & Paraguay & 0 & 0 & 0 & 0 \\
\hline Barbados & 1 & 1 & 0 & 0 & India & 0 & 1 & 0 & 1 & Peru & 0 & 0 & 0 & 0 \\
\hline Belgium & 0 & 0 & 0 & 0 & Indonesia & 0 & 0 & 0 & 1 & Philippines & 0 & 0 & 0 & 0 \\
\hline Benin & 0 & 0 & 0 & 0 & Iran & 0 & 0 & 1 & 1 & Portugal & 0 & 0 & 0 & 0 \\
\hline Bhutan & 1 & 1 & 0 & 0 & Iraq & 0 & 0 & 0 & 1 & Qatar & 0 & 0 & 1 & 1 \\
\hline Bolivia & 0 & 0 & 0 & 0 & Ireland & 1 & 1 & 0 & 0 & Rwanda & 0 & 0 & 0 & 0 \\
\hline Botswana & 0 & 0 & 0 & 0 & Israel & 1 & 1 & 0 & 0 & Samoa & 1 & 1 & 0 & 0 \\
\hline Brazil & 0 & 0 & 0 & 0 & Italy & 0 & 0 & 0 & 0 & Saudi Arabia & 0 & 0 & 1 & 1 \\
\hline Brunei & 1 & 1 & 0 & 0 & Jamaica & 1 & 1 & 0 & 0 & Senegal & 0 & 0 & 0 & 0 \\
\hline Burkina Faso & 0 & 0 & 0 & 0 & Japan & 0 & 0 & 0 & 0 & Sierra Leone & 1 & 1 & 0 & 0 \\
\hline Burundi & 0 & 0 & 0 & 0 & Jordan & 0 & 0 & 1 & 1 & Singapore & 0 & 1 & 0 & 1 \\
\hline Cameroon & 0 & 0 & 0 & 0 & Kenya & 0 & 0 & 0 & 1 & South Africa & 1 & 1 & 0 & 0 \\
\hline Canada & 1 & 1 & 0 & 0 & Korea (South) & 0 & 0 & 0 & 0 & Spain & 0 & 0 & 0 & 0 \\
\hline Central African Rep. & 0 & 0 & 0 & 0 & Kuwait & 0 & 0 & 1 & 1 & Sri Lanka & 1 & 1 & 0 & 0 \\
\hline Chad & 0 & 0 & 0 & 0 & Lebanon & 0 & 0 & 0 & 1 & Sudan & 0 & 0 & 1 & 1 \\
\hline Chile & 0 & 0 & 0 & 0 & Lesotho & 1 & 1 & 0 & 0 & Swaziland & 0 & 0 & 0 & 0 \\
\hline Colombia & 0 & 0 & 0 & 0 & Liberia & 1 & 1 & 0 & 0 & Sweden & 0 & 0 & 0 & 0 \\
\hline Congo Brazzaville & 0 & 0 & 0 & 0 & Libya & 0 & 0 & 1 & 1 & Switzerland & 0 & 0 & 0 & 0 \\
\hline Congo Kinshasa & 0 & 0 & 0 & 0 & Luxembourg & 0 & 0 & 0 & 0 & Syria & 0 & 0 & 1 & 1 \\
\hline Costa Rica & 0 & 0 & 0 & 0 & Madagascar & 0 & 0 & 0 & 0 & Taiwan & 0 & 0 & 0 & 0 \\
\hline Côte d'Ivoire & 0 & 0 & 0 & 0 & Malawi & 1 & 1 & 0 & 0 & Tanzania & 1 & 1 & 0 & 0 \\
\hline Cyprus G & 1 & 1 & 0 & 0 & Malaysia & 0 & 1 & 0 & 1 & Thailand & 0 & 0 & 0 & 0 \\
\hline Denmark & 0 & 0 & 0 & 0 & Maldives & 0 & 0 & 1 & 1 & Togo & 0 & 0 & 0 & 0 \\
\hline Dominican Rep. & 0 & 0 & 0 & 0 & Mali & 0 & 0 & 0 & 0 & Tonga & 1 & 1 & 0 & 0 \\
\hline Ecuador & 0 & 0 & 0 & 0 & Malta & 0 & 0 & 0 & 0 & Trinidad \& Tobago & 1 & 1 & 0 & 0 \\
\hline Egypt & 0 & 0 & 0 & 1 & Mauritania & 0 & 0 & 1 & 1 & Tunisia & 0 & 0 & 0 & 1 \\
\hline El Salvador & 0 & 0 & 0 & 0 & Mauritius & 1 & 1 & 0 & 0 & Turkey & 0 & 0 & 0 & 0 \\
\hline Equatorial Guinea & 0 & 0 & 0 & 0 & Mexico & 0 & 0 & 0 & 0 & Uganda & 1 & 1 & 0 & 0 \\
\hline Ethiopia & 0 & 0 & 0 & 0 & Mongolia & 0 & 0 & 0 & 0 & United Arab Emir. & 0 & 0 & 1 & 1 \\
\hline $\mathrm{Fiji}$ & 1 & 1 & 0 & 0 & Morocco & 0 & 0 & 1 & 1 & United Kingdom & 1 & 1 & 0 & 0 \\
\hline Finland & 0 & 0 & 0 & 0 & Nauru & 1 & 1 & 0 & 0 & United States & 1 & 1 & 0 & 0 \\
\hline France & 0 & 0 & 0 & 0 & Nepal & 1 & 1 & 0 & 0 & Uruguay & 0 & 0 & 0 & 0 \\
\hline Gabon & 0 & 0 & 0 & 0 & Netherlands & 0 & 0 & 0 & 0 & Venezuela & 0 & 0 & 0 & 0 \\
\hline Gambia & 0 & 1 & 0 & 1 & New Zealand & 1 & 1 & 0 & 0 & Zambia & 1 & 1 & 0 & 0 \\
\hline Ghana & 1 & 1 & 0 & 0 & Nicaragua & 0 & 0 & 0 & 0 & Zimbabwe & 1 & 1 & 0 & 0 \\
\hline
\end{tabular}

Notes: $\mathrm{Cl}=$ Common, $\mathrm{C2}=$ Common Strict. $\mathrm{M1}=$ Muslim Strict, M2 = Muslim Any. Civil law is the base case. The legal system classifications shown above are in agreement with the classification in Reynolds and Flores (1989). 


\section{NOTES}

(1.) Throughout, we use the terms political freedom and democracy interchangeably because researchers define these in a similar manner. For example, Barro (1999) uses the Freedom House (2002) indices of political rights and civil liberties to measure democracy.

(2.) The questions used in the annual Freedom House (2002) survey are described in the appendix. We omit from our tests countries with missing observations, primarily the newly created countries of the former Soviet Union.

(3.) Some countries could not be defined as having common, civil, or Muslim law and so were omitted from our cross-section empirical tests.

(4.) Carlino and Mills (1993) suggest this methodology as a test for income convergence.

(5.) The one-break minimum LM unit root test $b$, as similar properties to the two-break minimum LM test.

(6.) Gauss codes for the one- and two-break minimum LM unit root test are available online at www.cba.ua. edu/ jlee/gauss.

(7.) See Tomljanovich and Vogelsang (2002) for a similar application of the time-series notion of [beta]-convergence applied to per capita incomes of the U.S. regions.

(8.) The ten countries that are at the maximum level of freedom in each year of the sample period are Australia, Austria, Canada, Denmark, Iceland, Netherlands, New Zealand, Norway, Switzerland, and the United States. Seven other countries were also deleted because they were at or near the maximum freedom level most of the time: Barbados, Belgium, Costa Rica, Ireland, Luxembourg, Sweden, and the United Kingdom. North Korea was also deleted because its freedom index was always at the lowest level.

(9.) In this case, the log relative freedom series would be mean stationary with a mean equal to that of the world.

(10.) The results for natural resources squared are available from the authors on request.

(11.) Seventeen remaining countries are described as having predominately Muslim law (i.e., Afghanistan, Bahrain, Bangladesh, Iran, Jordan, Kuwait, Libya, Maldives, Mauritania, Morocco, Oman, Pakistan, Qatar, Saudi Arabia, Sudan, Syria, and the United Arab Emirates). Somalia cannot be classified as having predominately Muslim law but cannot be clearly characterized as common or civil law so was omitted from the regression tests in Tables 5 and 6.

(12.) Because we include legal type variables in our regressions and Barro (1999) did not, we are limited to a somewhat smaller sample of countries that can be jointly tested with these additional variables. The average values over the 1972-2001 period (for the available years) are used for these variables. 


\section{REFERENCES}

Banaian, K., and W. A. Luksetich. "Central Bank Independence, Economic Freedom, and Inflation Rates." Economic Inquiry, 39(1), 2001, 149-61.

Barro, R. J. "Economic Growth in a Cross Section of Countries." Quarterly Journal of Economics, 106(2), 1991, 407-43.

--. "Democracy and Growth." Journal of Economic Growth, 1(1), 1996, 1-27.

Barro, R. J. "Determinants of Democracy." Journal of Political Economy, 107(6), 1999, S158-83.

Barro, R. J., and J. W. Lee. "International Measures of Schooling Years and Schooling Quality." American Economic Review, Papers and Proceedings, 86(2), 1996, 218-23.

Barro, R. J., and X. Sala-i-Martin. "Convergence." Journal of Political Economy, 100(2), 1992, 223-51.

Baumol, W. J. "Productivity Growth, Convergence and Welfare: What the Long-Run Data Show." American Economic Review, 76(5), 1986, 1075-85.

Carlino, G., and L. Mills. "Are U.S. Regional Economies Converging? A Time Series Analysis." Journal of Monetary Economics, 32(2), 1993, 335-46.

Collier, P., and A. Hoeffler. "On the Economic Causes of Civil War." Oxford Economic Papers, 50(4), 1998, 563-73.

Dawson, J. W. "Institutions, Investment, and Growth: New Cross-Country and Panel Data Evidence." Economic Inquiry, 36(4), 1998, 603-19.

Evans, P. "Using Cross-Country Variances to Evaluate Growth Theories." Journal of Economic Dynamics and Control 20(6-7), 1996, 1027-49.

Evans, P., and G. Karras. "Convergence Revisited." Journal of Monetary Economics, 37(2), 1996, 249-65.

Farr, W. K., R. A. Lord, and J. L. Wolfenbarger. "Economic Freedom, Political Freedom and Economic Well-Being: A Causality Analysis." Cato Journal 18(2), 1998, 247-62.

Freedom House. Freedom in the World." The Annual Survey of Political Rights \& Civil Liberties: 2001-2002. New Brunswick, N J: Freedom House, 2002.

Friedman, M. "Do Old Fallacies Ever Die?" Journal of Economic Literature, 30(4), 1992, 212932.

Gwartney, J., R. Lawson, and R. Holcombe. "Economic Freedom and the Environment for Economic Growth." Journal of Institutional and Theoretical Economics, 155(4), 1999, 1-21. 
Gwartney, J., R. Lawson, and D. Samida. Economic Freedom of the World 2000 Annual Report. Vancouver, BC: Fraser Institute, 2000.

Hayek, F. The Constitution of Liberty. Chicago, IL: University of Chicago Press, 1960.

--. Law, Legislation and Liberty: A New Statement of the Liberal Principles of Justice and Political Economy, vol. I, 94. Chicago, IL: University of Chicago Press, 1973.

Helliwell, J. F. "Empirical Linkages between Democracy and Economic Growth." British Journal of Political Science, 24(2), 1994, 225-48.

Hotelling, H. "Review of The Triumph of Mediocrity in Business, by Horace Sechrist." Journal of the American Statistical Association, 28(184), 1933, 463-65.

Huntington, S. P. The Third Wave: Democratization in the Late Twentieth Century. Norman: University of Oklahoma Press, 1991.

La Porta, R., F. Lopez-de-Silanes, C. Pop-Eleches, and A. Sheifer. "The Guarantees of Freedom." Working paper, Harvard University. 2001.

La Porta, R., F. Lopez-de-Silanes, and A. Sheifer. "Law and Finance." Journal of Political Economy, 106(6), 1998, 1113-55.

Lee, J., and M. C. Strazicich. "Minimum LM Unit Root Test." Working paper, Department of Economics, University of Central Florida. 1999.

Lee, J., and M. C. Strazicich. "Break Point Estimation and Spurious Rejections with Endogenous Unit Root Tests." Oxford Bulletin of Economics and Statistics, 63(5), 2001, 535-58.

--. "Minimum LM Unit Root Test with Two Structural Breaks." Review of Economics and Statistics, 85(4), 2003, 1082-1089.

Li, Q., and D. Papell. "Convergence of International Output: Time Series Evidence for 16 OECD Countries." International Review of Economics and Finance, 8(3), 1999, 267-80.

Lipset, S. M. "Some Social Requisites of Democracy: Economic Development and Political Legitimacy? American Political Science Review, 53(1), 1959, 69-105.

Lumsdaine, R., and D. Papell. "Multiple Trend Breaks and the Unit-Root Hypothesis." Review of Economics and Statistics, 79(2), 1997, 212-18.

MacKinnon, J. G. "Critical Values for Cointegration Tests," in Long-Run Economic Relationships: Readings in Cointegration, edited by R. F. Engle and C. W. J. Granger. New York: Oxford University Press, 1991, chap. 13.

Mahoney, P. G. "The Common Law and Economic Growth: Hayek Might Be Right." Journal of Legal Studies, 30(2), 2001, 503-25. 
Mankiw, N. G., D. Romer, and D. N. Weil. "A Contribution to the Empirics of Economic Growth." Quarterly Journal of Economics, 107(2), 1992, 407-38.

Minier, J. A. "Is Democracy a Normal Good? Evidence from Democratic Movements." Southern Economic Journal, 67(4), 2001, 996-1009.

Ng, S., and P. Perron. "Unit Root Tests in ARMA Models with Data-Dependent Methods for the Selection of the Truncation Lag." Journal of the American Statistical Association, 90(429), 1995, 269-81.

Nunes, L., P. Newbold, and C. Kuan. "Testing for Unit Roots with Breaks: Evidence on the Great Crash and the Unit Root Hypothesis Reconsidered." Oxford Bulletin of Economics and Statistics, 59(4), 1997, 435-48.

Perron, P. "The Great Crash, the Oil Price Shock, and the Unit Root Hypothesis." Econometrica, 57(6), 1989, 1361-401.

Quah, D. "Galton's Fallacy and the Tests of the Convergence Hypothesis." Scandinavian Journal of Economics, 95(4), 1993, 427-43.

Reynolds, T. H., and A. A. Flores. Foreign Law: Current Sources of Codes and Basic Legislation in Jurisdictions of the World. Littleton, CO: Rothman, 1989.

Sachs, J. D., and A. M. Warner. "Economic Reforms and the Process of Global Integration." Brookings Papers on Economic Activity, 1, 1995, 1-118.

Scully, G. W., and F. M. Bass. "Relative Income and Investment Comparisons among OECD Nations." Technological Forecasting and Social Change, 59(3), 1998, 167-82.

Solow, R. "A Contribution to the Theory of Economic Growth." Quarterly Journal of Economics, 70(1), 1956, 65-4.

Tomljanovich, M., and T.J. Vogelsang. "Are U.S. Regions Converging? Using New Econometric Methods to Examine Old Issues." Empirical Economics, 27(1), 2002, 49-62.

United Nations Development Programme. Arab Human Development Report 2002. New York: United Nations, 2002.

Wu, W., and O. A. Davis. "The Two Freedoms, Economic Growth and Development: An Empirical Study." Public Choice, 100(1-2), 1999, 39-64.

Zivot, E., and D. W. K. Andrews. "Further Evidence on the Great Crash, the Oil-Price Shock and the Unit Root Hypothesis." Journal of Business and Economic Statistics, 10(3), 1992, 251-70. 